\title{
Pastor Silas Malafaia e o uso estratégico das mídias digitais: o novo púlpito religioso no cotidiano midiatizado
}

\author{
Pastor Silas Malafaia and the strategic use of digital media: the new \\ religious pulpit in everyday media
}

\section{Pastor Silas Malafaia y el uso estratégico de los medios digitales: el nuevo púlpito religioso en el cotidiano mediático}

Larissa de Oliveira Cesar ${ }^{1, a}$

lariissadeoliveira@gmail.com | https://orcid.org/o00o-0001-7200-2425

Patrícia Gonçalves Saldanha ${ }^{1, b}$

patsaldanha@gmail.com | http://orcid.org/oooo-0002-7041-129X

\footnotetext{
${ }^{1}$ Universidade Federal Fluminense, Programa de Pós-Graduação em Mídia e Cotidiano, Laboratório de Investigação em Comunicação Comunitária e Publicidade Social. Niterói, RJ, Brasil.

a Mestrado em Mídia e Cotidiano pela Universidade Federal Fluminense.

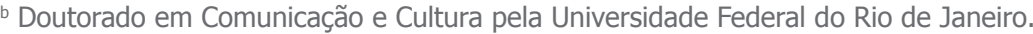

\section{Resumo}

Para compreender a tensão entre os conceitos de líder de opinião, desde sua formulação até a noção de influenciador digital na contemporaneidade, parte-se do pressuposto que a midiatização atravessa a vida cotidiana e pode afetar, portanto, suas mediações estruturantes, atravessando pensamentos e consumos sociais, com ênfase na religião. O trabalho que fundamenta este artigo se dividiu em duas etapas: a primeira utilizou como metodologia a revisão bibliográfica, tendo como eixo teórico Lazarsfeld e Sodré, aliada à pesquisa documental; a segunda consistiu em realizar uma análise de abordagem qualitativa no Twitter do pastor Silas Malafaia com o auxílio da ferramenta online WordArt, a fim de compreender a sua atuação como líder de opinião nas mídias digitais no que concerne às questões de gênero. Como resultado, concluímos que o pastor Malafaia influenciou a opinião de seu público ao retransmitir e ressignificar conteúdos sobre as questões de gênero enquanto 'ideologia de gênero' por meio das mídias digitais.

Palavras-chave: Líder de opinião; Midiatização; Influenciador digital; Gênero; Twitter; Mídias digitais; Religião. 


\begin{abstract}
In order to understand the tension between concepts of opinion former from its formulation to the notion of someone who has digital influence in contemporary times, we work on the assumption that the mediatization traverses our everyday life and can therefore affect its structuring mediations, crossing thoughts and social consumption, placing emphasis on religion. The study on which this paper is based was divided into two stages: at first it was developed a theoretical work, using as methodology the literature review taking the axis of Lazarsfeld and Sodré, followed by a documentary research. The second part consisted in carrying out a qualitative analysis of Pastor Silas Malafaia's Twitter helped by the online WordArt tool, in order to understand his opinion former role in digital media with regard to gender issues. The end result shows that Malafaia has influenced his public in retransmitting and re-signifying contents of gender issues as 'gender ideology' by means of digital media.
\end{abstract}

Keywords: Opinion former; Mediatization; Digital influencer; Gender, Twitter; Digital media; Religion.

\title{
Resumen
}

Para comprender la tensión entre los conceptos de líder de opinión, desde su formulación hasta la noción de influenciador digital en la contemporaneidad, se parte del supuesto que la mediatización atraviesa la vida cotidiana y puede afectar, por lo tanto, sus mediaciones estructurantes, atravesando pensamientos y consumos sociales, poniendo énfasis en la religión. El trabajo que fundamenta este artículo ha sido dividido en dos etapas: la primera fue teórica utilizando una metodología que conjuga la revisión literaria (en torno de Lazarsfeld y Sodré) y la investigación documental. En la segunda etapa, para comprender su actuación como líder de opinión en los medios digitales sobre las cuestiones de género, se realizó un análisis de enfoque cualitativo en el Twitter de Silas Malafaia con el auxilio de la herramienta online WordArt. Como resultado, hemos concluido que Malafaia ha influenciado a su público en la retransmisión y resignificación de contenido sobre temas de género como 'ideología de género' a través de los medios digitales.

Palabras clave: Líder de opinión; Mediatización; Influenciador digital; Género, Twitter; Medios digitales; Religión.

\begin{abstract}
Contribuição dos autores:
Concepção e desenho do estudo: Larissa de Oliveira Cesar e Patrícia Gonçalves Saldanha.

Aquisição, análise ou interpretação dos dados: Larissa de Oliveira Cesar e Patrícia Gonçalves Saldanha. Redação do manuscrito: Larissa de Oliveira Cesar e Patrícia Gonçalves Saldanha.

Revisão crítica do conteúdo intelectual: Larissa de Oliveira Cesar e Patrícia Gonçalves Saldanha.
\end{abstract}

Declaração de conflito de interesses: este trabalho não apresenta conflito de interesses.

Fontes de financiamento: CAPES - Coordenação de Aperfeiçoamento de Pessoal de Nível Superior

Considerações éticas: este estudo foi realizado durante o mestrado no Programa de Pós-graduação em Mídia e Cotidiano da Universidade Federal Fluminense e continua vinculado ao Laboratório de Investigação em Comunicação Comunitária e Publicidade Social (LACCOPS).

Agradecimento/Contribuições adicionais: não há.

Histórico do artigo: submetido: 28 jul. 2018 | aceito: 18 jan. 2019 | publicado: 29 mar. 2019.

Apresentação anterior: não houve.

Licença CC BY-NC atribuição não comercial. Com essa licença é permitido acessar, baixar (download), copiar, imprimir, compartilhar, reutilizar e distribuir os artigos, desde que para uso não comercial e com a citação da fonte, conferindo os devidos créditos de autoria e menção à Reciis. Nesses casos, nenhuma permissão é necessária por parte dos autores ou dos editores. 


\section{Introdução}

A formulação do conceito de líder de opinião foi feita no contexto da cultura de massa. Os estudos de Lazarsfeld, em 1940, apontaram a relevância do papel de influência do líder na sociedade da época. Atualmente, as mídias digitais modificaram as formas de comunicação, consumo e cultura da sociedade, reconfigurando a comunicação e as interações sociais a partir da mídia enquanto ambiência no fenômeno de midiatização, afetando, portanto, a atuação do líder de opinião no novo contexto.

O objetivo deste artigo é compreender a atuação do líder de opinião na sociedade midiatizada. Para isso, o trabalho, que faz parte de pesquisa de mestrado em desenvolvimento sobre o líder de opinião, religião e política, será estruturado em duas partes: trabalho teórico e análise de abordagem qualitativa realizada na conta oficial do Twitter do pastor evangélico neopentecostal Silas Malafaia. A rede social digital será tratada com maior profundidade mais à frente. Primeiramente, traçaremos um percurso do momento em que o conceito líder de opinião foi cunhado até o surgimento dos influenciadores digitais, considerando outras bases conceituais como a midiatização e a noção das mídias digitais. Para isso, será utilizada como metodologia a revisão bibliográfica aliada à pesquisa documental.

A partir da pesquisa bibliográfica é possível aprimorar o tratamento epistemológico com base em diferentes autores e teorias. O embasamento teórico será dado de acordo com a concepção de midiatização de Sodré ${ }^{1}$ um dos principais referenciais, do ponto de vista latino-americano, neste processo, e a de cotidiano de Heller². Será resgatado o conceito de líder de opinião de Lazarsfeld³, readequando sua aplicação na contemporaneidade. Para entender o contexto das mídias digitais será utilizado $\mathrm{Martino}^{4}$, que reúne diferentes teorias das novas mídias, bem como Recuero ${ }^{5}$ que reestrutura a conversação nas redes sociais, desta vez, digitais. Já a pesquisa documental foi fundamental para dar densidade ao texto, ao demonstrar dados comprobatórios levantados no decorrer da pesquisa de mestrado, ainda em desenvolvimento. Foram consultados os relatórios de pesquisa recentemente divulgados pelo Instituto Brasileiro de Opinião Pública e Estatística (Ibope) ${ }^{6}$, Instituto Brasileiro de Geografia e Estatística (IBGE) ${ }^{7}$, site We Are Social ${ }^{8}$ e pela Conferência das Nações Unidas sobre Comércio e Desenvolvimento (Unctad) ${ }^{9}$ e alguns dos dados obtidos serão detalhados no decorrer do texto.

Na segunda parte do estudo, analisaremos como Silas Malafaia se apresenta como influenciador digital, atuando na vida cotidiana a partir das redes sociais digitais, e também como líder de opinião, ao retransmitir e ressignificar conteúdos sobre as questões de gênero para o nicho cristão enquanto 'ideologia de gênero'. O recorte de tempo analisado se estende do dia 9 de setembro de 2017 a 9 de dezembro do mesmo ano e foi escolhido após ser identificado na ferramenta Google Trends como o período de ápice de busca da expressão 'ideologia de gênero' no Google. Foi feita uma análise do Twitter de Silas Malafaia com o uso da ferramenta online WordArt e abordagem qualitativa, com a criação de um mapa conceitual das expressões usadas pelo pastor para referir-se às questões de gênero.

\section{O modelo de comunicação em dois níveis}

A concepção de líder de opinião se deu no contexto da Segunda Guerra Mundial, com a utilização dos meios de comunicação de massa. Lazarsfeld, Berelson e Gaudet estudaram de que forma os líderes de opinião influenciaram o voto das pessoas na Comunidade de Ohio, nos Estados Unidos, durante a eleição presidencial de 1940. O estudo foi denominado "A escolha das pessoas. Como o eleitor elabora suas decisões numa campanha presidencial"3.

A proposta parte do entendimento de que as dinâmicas sociais se cruzam com o processo de comunicação, em que o líder de opinião exerce um importante papel de influência sobre a sociedade. Segundo Mauro Wolf ${ }^{10}$, a abordagem faz parte dos estudos de comunicação designados "abordagem empírica em campo" ou, 
ainda, "efeitos limitados", que reconhecem a fragilidade dos efeitos dos meios de comunicação por si só, desconsiderando as dinâmicas sociais que ocorrem no processo da recepção das mensagens.

De acordo com a proposição do modelo de comunicação em dois níveis, ou two step flow of communication, o líder de opinião seria mediador entre os meios de comunicação de massa (MCM) e os indivíduos menos informados. O modelo se estrutura em dois níveis, em que o primeiro consistiria na transmissão das mensagens dos MCM aos líderes de opinião (a), enquanto o segundo relaciona-se ao processo de influência do líder de opinião (LO) sobre a apreensão dos outros indivíduos (b).

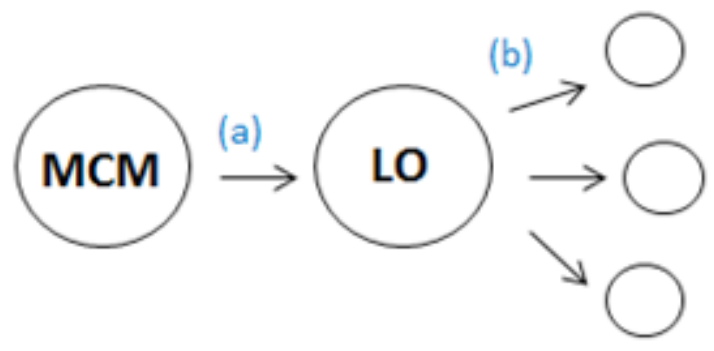

Figura 1 - Modelo de comunicação em dois níveis

Fonte: As autoras (2018).

Diferentemente, do modelo two step flow, a Teoria Hipodérmica (também conhecida por 'Teoria da Bala Mágica'), cuja ideia central se baseia no esquema estímulo e resposta, numa suposição determinista, fundamentou-se em um dos primeiros estudos comunicacionais elaborados, em 1910, por Harold Lasswell, mas foi desenvolvida no período entre as guerras mundiais. Ao se referir aos efeitos da mídia na sociedade, o modelo da Teoria Hipodérmica se fundamentava na manipulação da massa, ao propor que a mensagem veiculada pelos meios de comunicação surtiria um efeito direto de persuasão ao ser recebida pelo indivíduo. Acreditava-se, na onipotência dos meios de comunicação de massa (MCM), pois, à medida que a propaganda fosse emitida causaria o efeito desejado no ato de sua recepção. Metaforicamente, afirmava-se que a mensagem seria uma agulha capaz de injetar suas ideias no tecido social que, por sua vez, seriam absorvidas por seus receptores, sem esboçar reações, como se fossem uma massa amorfa: tratava-se da agulha hipodérmica. Nesse contexto, o receptor foi intitulado de 'homem-massa', característico pela alienação, uniformidade e isolamento social. Esses seriam sujeitos passivos sem capacidade reflexiva e sem interferência na opinião de outros. O modelo consiste no esquema emissão-mensagem-receptor.

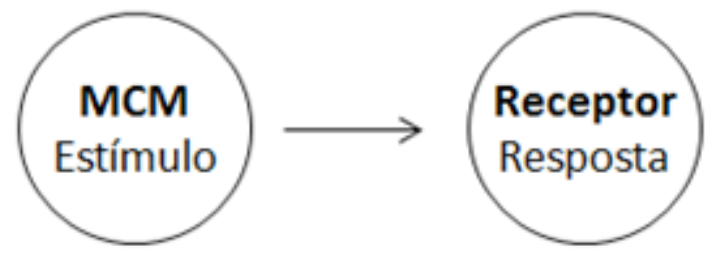

Figura 2 - Modelo Estímulo-Resposta Fonte: As autoras (2018)

Os MCM (ou emissor) geram um estímulo (ou mensagem) que, por meio de um processo de persuasão, atinge o receptor isolado, gerando uma resposta. Essa última, no caso, o convencimento por meio da mensagem emitida, seria a resposta desejada pelo emissor. Logo, se na Teoria Hipodérmica, o esquema se constituía pela manipulação, no two step flow se fundamenta na influência, não necessariamente pela mídia, mas a partir das relações entre os sujeitos, das quais os MCM também fazem parte. 
$\mathrm{Na}$ Teoria dos Efeitos Limitados, os líderes de opinião são os indivíduos com muito interesse e envolvimento em um tema, representam a "parcela da opinião pública que procura influenciar o resto do eleitorado e que demonstra uma capacidade de reação e resposta mais atentas aos acontecimentos" ${ }^{\text {”o }}$. São sujeitos mais ativos no que concerne aos assuntos políticos e mais decididos no processo de formação de voto. A opinião deles pesa mais do que a dos próprios meios de comunicação de massa para a apreensão da opinião dos indivíduos, pois estabelecem contato pessoal maior que o dos MCM.

O cientista político, Emerson Cervi ${ }^{11}$, defende que o líder de opinião é um dos componentes integrantes do processo de formação e transformação da opinião pública, já que ocupa posição privilegiada no espaço público, capta informações de interesse público provenientes de fontes distintas, reformula seus significados e retransmite aos demais integrantes de esferas públicas específicas. Assim, sua atuação diminui a influência direta dos meios de comunicação.

Para $\operatorname{Cervi}^{11}$, o indivíduo opera com maior liberdade de escolha que nas sociedades que ainda não conviviam com a mídia. Isso porque é possível escolher os interlocutores pelo qual deseja se informar, a fim de formar sua opinião. Antes, as relações sociais baseavam-se no grupo social ao qual pertencia e suas opiniões, por consequência, também eram formadas nessa estrutura. Atualmente, a opinião de um indivíduo é constituída como resultado da união dos elementos informação e predisposição. Nesse caso, para Zaller ${ }^{12}$, citado por Cervi $^{11}$, a informação é responsável por formar uma imagem mental sobre um assunto, enquanto a predisposição estimula conclusões a respeito dessa mesma imagem.

Estudos posteriores, como de Merton ${ }^{13}$, citado por Wolf ${ }^{10}$, buscaram ainda caracterizar os líderes de opinião de acordo com sua articulação no espaço público e suas formas de influência, distinguindo entre dois tipos: o líder de opinião local e o cosmopolita. O primeiro está inserido na vida da comunidade, não tem competências específicas; por isso, exerce influência em diversas esferas temáticas e é denominado polimórfico. Além disso, tem contato interpessoal com o maior número possível de pessoas, o que define seu papel de influência mais por conhecer muita gente do que por dominar uma temática específica e consome meios mais populares, como rádio e jornal.

Já o cosmopolita prioriza a qualidade e seleção de seus contatos, domina competências específicas e exerce autoridade para falar de temáticas particulares; é chamado de líder monomórfico. É um pouco conhecido por todos, embora seu ciclo social seja mais seleto. Consome meios de comunicação considerados mais 'elevados', como revista. Então, conclui-se que a diferença entre os líderes de opinião local e cosmopolita se dá de acordo com as formas de consumo dos MCM e as dinâmicas de circulação das informações, com os motivos que os tornam influente e com as estruturas sociais em que se inserem. Outro ponto relevante é que o líder de opinião exerce sua influência em outras esferas de interesse que ultrajam a política, conforme o estudo empírico realizado antes por Lazarsfeld 3 .

Se Merton distingue os líderes de opinião entre locais e cosmopolitas, Cervi ${ }^{11}$, em estudos mais atuais sobre o líder de opinião e os MCM, os diferencia como líderes verticais e horizontais, dando ênfase à folkcomunicação, ou comunicação popular. O líder vertical ocupa posições sociais de alta visibilidade nos MCM, tais como âncoras de telejornais, políticos ou representantes de segmentos sociais com presença contínua nos meios de comunicação, sendo líder ou representante de alguma organização social. Já o líder horizontal ou folk-comunicador desempenha o papel de difusor de informação em pequenos grupos, desenvolvendo capacidade de persuasão por sua credibilidade, respeito e carisma pessoal.

Os líderes de opinião verticais ocupam posições privilegiadas nos MCM, porém, geralmente, não tem acesso aos meios de comunicação popular. Já os líderes horizontais são o oposto, uma vez que não possuem instrumentos de difusão de massa e estão mais presentes na comunicação popular. São mais sensíveis que os demais integrantes locais e sentem necessidade de se manifestarem a respeito de assuntos de interesse público, funcionando como mediadores para os cidadãos comuns menos interessados no debate público. 
O líder de opinião horizontal, também chamado de popular recebe a mensagem dos meios de comunicação e adequa seus significados para retransmitir o conteúdo de acordo com a realidade das camadas populares, tornando-o acessível e compreensível para os receptores. Considerando que a mídia transmite um conteúdo padronizado sem distinção de grupos sociais específicos, cabe ao líder de opinião folk interpretar o conteúdo comunicacional dos meios de massa e estimular a participação social na formação da opinião em pequenos grupos sociais.

Cervi argumenta que, mesmo que receba o conteúdo das mensagens direto da mídia, "o público precisa, na maioria das vezes, de referenciais com os quais possa se identificar socialmente e buscar auxílio na interpretação de códigos não totalmente adaptados à realidade de cada grupo social”" ${ }^{11}$. Essa atribuição é exercida pelos líderes de opinião horizontais, que transformam a mensagem emitida pela mídia para a recepção local, funcionando como "formadores de percepções, apropriações e aceitações de conteúdo"11.

A divisão da comunicação em dois níveis implicou numa redução do papel determinista dos meios de comunicação como difusores de informação, em que a mediação e as relações sociais que se estabelecem entre o líder de opinião e os liderados têm importância no processo de formação de opinião. Por isso, os efeitos gerados pelos meios de comunicação de massa "dependem das forças sociais que prevalecem num determinado período" O autor oferece ainda alguns dados importantes em relação ao contexto da formulação do líder de opinião, que merecem destaque. Nos anos 1940, a oferta de meios de massa disponíveis na sociedade era baixa, evidenciando o papel do líder de opinião no exercício da função de mediador e difusor de conteúdo na comunicação interpessoal.

Apesar de na atualidade existir uma oferta muito maior de MCM, destacando ainda o protagonismo da televisão, o líder de opinião continua exercendo papel de influência; porém, sua zona se deslocou do nível interpessoal para o ambiente midiático. Para $\mathrm{Morgado}^{14}$, o líder de opinião midiático continua atuando como o líder local, assumindo o papel de intérprete da voz do poder público junto aos que influencia, mantendo-os informados sobre os acontecimentos.

O processo é mais complexo do que aparenta. A configuração social e dos meios de comunicação sofreu alterações desde a formulação de Lazarsfeld em 1940, no contexto de uma sociedade de massa incipiente, e se ampliou com a expansão da televisão. A mídia ganhou espaço central na experiência cotidiana dos sujeitos, tornando-se ponto de contato entre as pessoas ${ }^{3}$, especialmente a partir da internet. Por isso, para entender a atuação do líder de opinião contemporâneo, é necessário entender a nova configuração social e tecnológica que se estabelece e apreender o atual conceito de midiatização.

\section{O processo de midiatização do cotidiano}

Os estudos sobre midiatização se fortaleceram, principalmente, a partir dos anos 2000. Por se tratar de um campo teórico em construção ainda recente, não há consenso sobre o que é a midiatização de fato, mas há pistas cada vez mais sólidas. Existem linhas de pesquisa bem definidas que, inclusive, foram discutidas no II Seminário Internacional de Pesquisa em Midiatização e Processos Sociais, realizado na Unisinos, no Rio Grande do Sul recentemente. O evento que teve como um de seus objetivos situar o Brasil nas pesquisas sobre a midiatização, tratou da tensão do campo entre as duas vertentes epistemológicas: uma que parte do Sul, em países como Brasil e Argentina; e outra dos países do Norte como os Estados Unidos, além de outros da Europa Setentrional, como a Dinamarca, por exemploi.

No presente estudo, optou-se pelas definições que privilegiam o contexto latino-americano e brasileiro. Por isso, as abordagens teóricas partirão de autores dessa realidade, como Muniz Sodré e Martín Barbero. Ainda existe uma confusão epistemológica entre os conceitos de mediação e midiatização, causado pelos usos distintos da palavra mídia ou media, suas origens e aplicações. Ambas as definições, mediação e

\footnotetext{
i Veja mais no portal oficial do evento. Disponível em: http://www.unisinos.br/eventos/ii-seminario-internacional-de-pesquisa-emmidiatizacao-e-processos--ex123394-00001 Acesso em 15 de abr. de 2018.
} 
midiatização, são pertinentes e necessárias no trabalho desenvolvido, visto que incorrem na relação entre mídia e sociedade, em que a religião também ocupa um espaço importante.

Mediação é o "processo cultural complexo de negociação de sentido entre produtores e receptores de uma mensagem"4. O conceito foi formulado pelo teórico colombiano Jesús Martín-Barbero que introduziu, na década de 1980, a Teoria das Mediações. A concepção funciona como uma reação em relação à onipotência dos meios de comunicação de massa. Isto, porque se admite o entendimento de que os meios de comunicação de massa não são os as únicas fontes de difusão de conhecimento e informação. As estruturas e vinculações sociais e estruturas que se formam na relação e interação com os meios também têm importância no processo de produção de sentido, e não devem ser vistas apenas a partir ou sob determinação deles.

Distanciando-se da ideia de manipulação, Barbero ${ }^{15}$ propõe que existe uma articulação entre os significados transmitidos nas mensagens midiáticas e o que será apreendido no cotidiano dos indivíduos. Segundo a proposição latino-americana, para além da mídia, existem mais instituições mediadoras, tais como igreja, escola, sindicato e outras relações no espaço de sociabilidade que ocorrem no cotidiano e que podem provocar mudanças nos sujeitos. Para ele, há um espaço entre o estímulo e a resposta, o qual as instituições mediadoras ajudam a preencher, configurando crenças, costumes e pensamentos, onde, de fato, a comunicação acontece.

Já o conceito de midiatização propõe o ganho de vida própria pela mídia no espaço social, que vem sendo chamado por Sodré ${ }^{1}$ de 'bios midiático', e assume centralidade e atravessa o cotidiano dos sujeitos. A concepção ganhou força especialmente com a popularização da televisão e, recentemente, da internet. Segundo pesquisa do Instituto Brasileiro de Geografia e Estatística (IBGE) divulgada em $2018^{7}$, a televisão está presente em mais de $90 \%$ dos domicílios do país, aparecendo na média nacional em $96,8 \%$ dos lares. A despeito da internet, a televisão ainda é a principal fonte de informação para $63 \%$ dos brasileiros, de acordo com relatório realizado pelo Instituto Brasileiro de Opinião Pública e Estatística (Ibope) ${ }^{6}$. Entretanto, a internet já ocupa o segundo lugar na pesquisa, despontando como meio preferido para $26 \%$ dos entrevistados, deixando para trás o rádio, o jornal impresso e a revista. O número vem crescendo significativamente, conforme será abordado no tópico posterior, e demonstra a ampla presença da mídia na rotina das pessoas, funcionando, inclusive, como meios fundamentais para busca de informação. Informação essa que pode ser transformada em opinião.

Entre as várias correntes que tratam a midiatização, nos pautaremos em duas: a institucionalista e a sócio construtivista. A primeira linha de pensamento defende a mídia como instituição capaz de ditar regras de sistemas sociais, enquanto a segunda se refere a uma construção social midiatizada, com enfoque nos aspectos culturais e especificidades de cada mídia ${ }^{16}$. No Brasil, Muniz Sodré é um dos principais teóricos da área. Em sua obra, Antropológica do espelho - uma teoria da comunicação linear e em rede ${ }^{1}$ o autor propõe que a mídia se compõe como uma nova forma de vida. Sodré faz uma releitura dos três tipos de vida, ou bios, propostos por Aristóteles no livro 'Ética a Nicômaco', em que existe uma vida guiada pelo prazer; outra direcionada à vida política e, por fim, tem-se a vida contemplativa. Para o autor, a mídia seria o quarto tipo de vida ou bios. Dentro desta concepção, a mídia apresenta poder para vilipendiar as relações sociais, tornando-se aparato social para a modulação de ideias, valores, pensamentos e comportamentos de acordo com os interesses do mercado, de quem é porta-voz.

As relações humanas e as práticas sociais se articulam com a mídia na vida cotidiana contemporânea, de forma que os meios de comunicação alteram tais atividades e suas apropriações passam a ser tão naturalizadas que correm o risco de se tornarem invisibilizadas. É o que $\mathrm{Martino}^{4}$ define como processo de midiatização e permite apontar para o cenário, a partir de diferentes teóricos, que nos encontramos de uma sociedade midiatizada.

Em uma das primeiras obras que trata sobre a midiatização, Sodré ${ }^{1}$ define o termo como sendo uma espécie de mediação realizada no âmbito da comunicação, com um tipo específico de interação consubstanciado a partir das tecnologias, chamada de "tecnointeração". Em obra mais recente do autor, "A ciência do comum”", entretanto, o fenômeno é tratado como sobreposição às mediações socioculturais, visto que estas têm sido atravessadas pela lógica do mercado em todas as esferas da vida, em prol de uma remodelação para posterior serventia. Apresentando poder para ganhar vida própria no espaço social, o sentido produzido pelos meios de comunicação ultraja os 
processos de produção dos veículos comunicativos, pautando a sociedade, produzindo sentido e remodelando valores que ajudam a delinear a opinião pública de forma cada vez mais rápida ${ }^{17}$.

Nessa perspectiva, para Patrícia Saldanha, o capitalismo se apropriou dos aparatos tecnológicos, suprimindo o espaço pelo tempo, enquanto a midiatização "passou a gerir sentimentos, emoções e afetos e, consequentemente, a comunicação assumiu papel estratégico, uma vez que é capaz de produzir riquezas materiais e imateriais, que são substanciais para a manutenção do vigor das relações humanas"18.

O papel desempenhado pelo líder de opinião e a sua atuação em uma sociedade midiatizada possibilita estabelecer um paralelismo entre os elementos, envolvidos na propagação de mensagens e valores, e a cotidianidade. A transmissão de informações se transformou a partir do processo de midiatização' ${ }^{1}$, revelando o cotidiano como midiático. Com a internet e as redes sociais (agora digitais), este processo acontece de forma mais imediata. A forte presença dos brasileiros nas redes sociais demonstra o caráter hierárquico do cotidiano, em que a mídia ocupa espaço alargado na vida dos sujeitos. Tal comportamento será abordado na próxima seção.

O cotidiano é vivenciado pelo homem com todos os aspectos de sua individualidade e é caracterizado por ser heterogêneo, já que a vida possui esferas de conteúdo e significação distintas entre si; e hierárquica, dada à priorização de algumas atividades em detrimento de outras, conforme circunstâncias mutáveis. Heller diz que "a vida cotidiana é a vida de todo homem. [...] o homem participa na vida cotidiana com todos os aspectos de sua individualidade, de sua personalidade. Nela, colocam-se 'em funcionamento' todos os seus sentidos, todas as suas capacidades intelectuais, suas habilidades manipulativas, seus sentimentos, suas paixões, ideias, ideologias. [...] A vida cotidiana é, em grande medida, heterogênea; e isso, sob vários aspectos, sobretudo no que se refere ao conteúdo e à significação ou importância de nossos tipos de atividade. [...] Mas a significação do conteúdo, tal como seu conteúdo, não é apenas heterogênea, mas igualmente hierárquica. [...] O homem nasce já inserido em sua cotidianidade"

Logo, todo homem nasce inserido na vida cotidiana. Para a autora, os pensamentos e atividades nesse cotidiano heterogêneo e hierárquico são operados por mecanismos fundamentais para que o homem viva na cotidianidade, tais quais o economicismo, a ultrageneralização, a entonação e a mímese. Heller aponta ainda que todo indivíduo é ser genérico e particular. No que diz respeito à particularidade, ela afirma que as suas características são unicidade e irrepetibilidade, o que demonstra o modo singular do indivíduo. Entretanto, este também é homem-genérico, sendo fruto das relações sociais que o compõem, o que se constitui um atributo importante, levando em consideração as possibilidades de afeto do líder de opinião.

A autora afirma que o cotidiano pode funcionar como um espaço propício à alienação, embora esta não necessariamente ocorra. Isto se justifica pelo elemento espontaneidade, apontado como característica dominante na vida ordinária. Refere-se ao agir de forma mecânica, automatizada. Os usos dos mecanismos são feitos para facilitar o deslocamento do sujeito no dia a dia. Heller disserta sobre o pensamento cotidiano estar vinculado às atividades; por isso, as ideias necessárias ao cotidiano não se elevam de modo a alcançar o nível da teoria. Neste sentido, a fé e a confiança desempenham papel muito importante no dia a dia, já que possuem caráter pragmático. O pensamento cotidiano, então, é o da ultrageneralização, que consiste na utilização de juízos provisórios para agir da forma mais rápida possível.

Por isso, é imprescindível apreender que o sujeito é constituído a partir das relações e interações sociais. O cotidiano ambientado pela mídia facilita a transformação da informação difundida pelo líder em opinião que pode vir a orientar o liderado por meio de um processo de assimilação, baseado na confiança e, no caso dos religiosos, também na fé. Na sociedade midiatizada, há uma exacerbação dos meios de comunicação que perpassam a vida cotidiana dos sujeitos e instituições, ampliando a realidade existente e naturalizando o uso da tecnologia, bem como dos produtos pré-fabricados e dos serviços de inovação, além de estabelecer regimes de poder a partir das indústrias de mídia. A midiatização começou a ser estudada no cenário dos MCM, porém o fenômeno também se intensificou com as novas mídias, tratando-se da natureza de transformação rápida e ubíqua das mídias digitais. 


\section{Comunicação digital, influenciador digital e o líder de opinião contemporâneo}

Como é comum nos estudos científicos, existem divergências sobre o conceito de mídias digitais. $\mathrm{Martino}^{4}$, entretanto, destaca que a expressão é uma tentativa de diferenciar as novas mídias das analógicas, também chamados de meios de comunicação de massa, como televisão, rádio e jornal impresso. A diferença substancial reside no aparato técnico concreto para o funcionamento das mídias analógicas, enquanto as mídias digitais operam por meio de sequências de números ou dígitos interpretados por computador, o que permite o compartilhamento, armazenamento e conversão desses dados. Portanto, o aparato físico, no caso das digitais, tem menor importância.

O autor esquematiza um quadro conceitual, compilando as principais características das mídias digitais elaboradas com base em pensadores e suas respectivas posições teóricas, que deram importantes contribuições para entender a cultura digital. Destacam-se para este trabalho a interatividade, segurança e vigilância, ubiquidade, velocidade e virtualidade. A interatividade permite a interação entre diferentes usuários de diferentes maneiras por meio da comunicação digital. No que se refere à segurança e à vigilância, destaca-se o fato de que as mídias digitais proporcionam uma comunicação mais viável de identificação e rastreamento dos dados. Ubiquidade e velocidade revelam que a comunicação digital está presente em todos os lugares e, através da rede, põe em contato indivíduos em diferentes espaços físicos e tempos, por intermédio de uma conexão rápida e articulável a diferentes atividades da vida cotidiana.

Um estudo realizado pela Conferência das Nações Unidas sobre Comércio e Desenvolvimento (Unctad), divulgado recentemente, revelou que o Brasil já é o quarto país em número de usuários na internet $^{9}$. Com 120 milhões de pessoas conectadas, o país fica atrás somente de Estados Unidos, Índia e China. Comparados proporcionalmente à população, os dados mostram que o país possui $59 \%$ de usuários da internet. Número muito inferior comparado ao Reino Unido, que tem o maior número de usuários comparado à população, chegando a 94\%.

O Brasil, porém, é o país onde a população passa mais tempo na internet e o segundo em matéria de acesso às redes sociais, segundo estudo da organização We Are Social ${ }^{8}$. Cada brasileiro gasta em média cinco horas e doze minutos por dia em computadores e três horas e 55 minutos em dispositivos móveis. Os altos índices brasileiros podem ser comprovados pela maior oferta de dispositivos móveis, como smartphones e tablets, na vida cotidiana. A principal plataforma de acesso à internet no Brasil é o smartphone, o que corrobora os argumentos de interatividade, velocidade e ubiquidade das mídias digitais. O quesito interação torna-se ainda mais relevante para tratar da proposta do artigo, possibilitando a atuação do líder de opinião entre diferentes usuários como um influenciador nas mídias digitais, principalmente, nas redes sociais.

O número de usuários de internet pelo celular aumentou 92\%, já abrangendo 100,8 milhões de brasileiros; quanto aos usuários da rede pelo celular que acessam a internet todos os dias disparou 149\%, para 95,5 milhões de habitantes, enquanto aqueles que acessaram as redes sociais pelo celular nos últimos três meses avançaram 110\%, passando de 43,0 para 90,2 milhões de pessoas. O número de usuários de internet por meio do celular cresceu 125\%, passando para 117,2 milhões de brasileiros em 2016. Os índices comprovam como a internet está presente na rotina das pessoas, modificando a forma de difusão de informação, a cultura, as relações sociais, o consumo e, também, a comunicação política.

Alguns debates se formam em torno da individualização provocada pela comunicação digital. Porém, as discussões não são novas, pois, desde o século XX, com o uso da televisão, os pesquisadores falavam de isolamento, em teorias da comunicação primordiais, como a da agulha hipodérmica. Uslaner ${ }^{19}$, citado por Marques ${ }^{20}$, defende a ideia que, apesar do distanciamento que o indivíduo foi obtendo em relação à família e a outros ciclos sociais, a conversação em rede cria novos espaços, que geram a aproximação de outros sujeitos e criação de laços comunitários, construídos a partir da confiança e do compartilhamento de interesses em comum. 
Nesse sentido, o pensamento de Cervi ${ }^{11}$ utilizado no início deste artigo reafirma a proposição quando fala dos MCM e de individualização, em que as opiniões e grupos sociais do sujeito são escolhidos a partir de suas preferências pessoais, o que não acontecia na era pré-midiática. Na era da internet essa realidade é acentuada, uma vez que facilita a pesquisa e busca indivíduos com interesses e pensamentos em comum. A pesquisadora Raquel Recuero defende que as redes sociais construídas online são resultantes da apropriação da técnica e das ferramentas da internet para comunicação com a interação entre diferentes pessoas. Logo, as redes sociais não seriam os sites e a ferramenta em si, mas a construção social e a produção de sentido a partir do uso da tecnologia. A ampla incorporação de dispositivos digitais como práticas de comunicação no cotidiano das pessoas proporcionou espaços conversacionais, ou seja, "espaços onde a interação com outros indivíduos adquire contornos semelhantes àqueles da conversação, buscando estabelecer/manter laços sociais"s.

A internet proporcionou então uma simulação de um ambiente interfacial onde, mediante a apropriação da técnica, é possível manter laços que se assemelham ao contato interpessoal, aproximando diferentes pessoas, ainda que separadas do ponto de vista do espaço físico. Esta construção social viabiliza um ambiente propício para o líder de opinião atuar por meio de conversações em rede com outras pessoas em um ambiente de proximidade, no qual é possível se estabelecerem relações.

No panorama da cultura participativa, empreende- $\mathrm{se}^{3} \mathrm{o}$ argumento que a partir das mídias digitais qualquer pessoa tem potencial para ser produtor de conteúdo e difusor de informação. A concepção é coerente, pois a internet abriu canais de comunicação que viabilizam a emergência de diferentes vozes. Porém, a produção de conteúdos por quaisquer indivíduos não garante que a opinião e a informação emitidas nas redes culminarão em um processo de influência. Há que se considerar, especialmente, a hegemonia de grandes empresas de comunicação e informação que estabelece uma cultura digital voltada para a alimentação do mercado e propicia um cenário em que algoritmos podem interferir para quem chegará uma informação conforme seu conteúdo.

É importante ressaltar que, na atualidade, com a difusão das mídias digitais que atravessam o cotidiano do cidadão comum de maneira imediata, surgiu a denominação influenciador digital. O nome é recente e no uso comum tem sido intercambiado por vocábulos, como formador de opinião e, até mesmo, líder de opinião. No desenvolvimento deste trabalho, foi possível entender uma diferença limítrofe entre os conceitos de influenciador digital e líder de opinião, apesar de apresentarem algumas semelhanças entre si.

Por ser um vocábulo recente, ainda carece de maior consistência no campo teórico, porém, já existem contribuições para entender o conceito, sobretudo, da perspectiva do marketing. A literatura sobre a temática se aproxima ainda dos estudos sobre celebridades, em que a atuação deste tipo de influenciador está relacionada à lógica mercadológica. Em pesquisa que endossa a discussão sobre o conceito e as práticas do influenciador digital, Karhawi registra o desenvolvimento do termo a partir de outros já conhecidos, tratando o "eu como mercadoria"

O vocábulo começou a ser mais difundido a partir de 2015 com o amplo uso de diferentes plataformas pelos influenciadores digitais ${ }^{22}$, até então denominados de acordo com a plataforma originária de atuação, tais quais blogueiro (sujeito que publica conteúdo pessoal em blogs), vlogueiros (produtor de vídeos pessoais. Adaptação do termo blogueiro), instagrammers (produtor de conteúdo monetizado na rede social Instagram), youtubers (produtor de vídeos monetizados na mídia social Youtube) e creators (criadores de conteúdo). O termo, advindo do inglês digital influencer, abarca os que utilizam várias redes numa atuação multiplataforma (Youtube, Facebook, Instagram, Snapchat etc.) para produzir e difundir conteúdo.

Essa lógica admite a cultura participativa como processo em que todos podem influenciar, já que há uma diferença entre a sociedade de massa e a de rede. Na primeira, a transmissão da mensagem ocorre de um para muitos, enquanto na segunda, existem diversos nichos, pequenos grupos, muitos falam para muitos. Os influenciadores atuam em nichos e se destacam por dois motivos principais, segundo a autora: 1) são necessários como filtro da informação que chega aos diferentes públicos da rede e 2) reúnem atributos que 
conferem a eles credibilidade, reputação e prestígio. Influenciador digital dá nome a um profissional cuja prática está atrelada a relações com marcas, empresas e pessoas convertidas em ganhos monetários ${ }^{22}$.

Ou seja, ele usa sua imagem como moeda de troca, monetizando a exibição, não só dela como também do conteúdo que produz. Logo, é uma profissão, o que não ocorre necessariamente com o líder de opinião. Este pode ser um influenciador digital, mas nem todo influenciador digital é um líder de opinião. Ademais, a prática do influenciador digital se consubstancia como prática profissional no ambiente digital, enquanto o líder de opinião pode ser influente extrapolando as mídias digitais, sendo conhecido em outras mídias e, inclusive, fora delas. O influenciador digital atua em seu ninho digital, enquanto o líder de opinião transgride seu nicho, influenciando a opinião pública.

No escopo dos influenciadores digitais, assume-se que há sempre produção de conteúdo que será convertido em capital material ${ }^{22}$. Para além dessa posição, há uma perspectiva que qualifica as relações estabelecidas no ambiente digital a partir dos níveis operantes da comunicação propostos por Sodré, sendo eles vinculação, relacional e crítico-cognitivo ${ }^{17}$. O argumento de Sodré é que a vinculação promove a união afetiva de um grupo, estabelecendo um diálogo recíproco que extrapola a ordem midiática e se distingue da relacional, proveniente da interação promovida pela rede que se mantém na lógica que atende aos interesses do mercado.

Nesse sentido, o influenciador digital se localiza no nível comunicativo relacional, em que a relação social que se estabelece é estruturada de forma epidérmica e superficial nos moldes do mercado, apesar de ser uma interação construída na falsa aparência de vínculo, pois o fim é a monetização da imagem e do conteúdo. Já o nível operacional em que atua o líder de opinião é o do vínculo, à medida que se estabelece uma relação de confiança unindo comunidade, vinculação e interesses em comum. No caso da religião, a relação de confiança se conforma na fé.

A comprovação de uma nova configuração de afetos entre mídia, cultura e sociedade diferentes dos vividos pelo líder de opinião desde os anos 40 do século passado demanda uma reconfiguração do conceito, considerando o processo de midiatização e a comunicação digital. Por isso, este artigo evoca o modo de atuação contemporâneo do líder de opinião, o qual se estabelece não com função de filtro dos meios de comunicação de massa somente. Hoje, o público também tem acesso direto aos meios. O líder continua liderando a opinião pública, porém, como referência não só nos MCM, mas também nas mídias digitais e ainda no espaço extra mídias. Entretanto, concomitantemente aos meios de massa, existem as mídias digitais, em que também atuam os influenciadores digitais em interação com o público em uma via de mão dupla. Todavia, nem sempre eles agem como líder de opinião na grande mídia, pois atuam no nível relacional da interação. Houve, portanto, um deslocamento do líder de opinião que age por dentro e por fora da mídia, pois a questão ultraja os meios e está no que ele representa para o público.

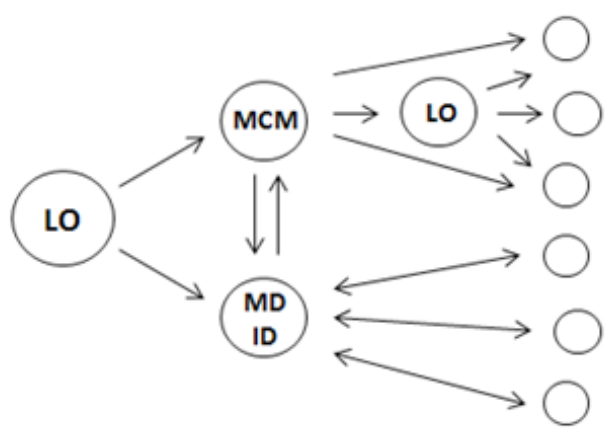

Figura 3 - Líder de opinião contemporâneoii

ii O esquema proposto foi criado pela autora Patrícia Saldanha, referência nos estudos de comunicação comunitária e publicidade social com enfoque na midiatização, e trata-se de uma construção coletiva de reflexão teórica com a autora Larissa Cesar; bem como com a contribuição de Magali Cunha, referência nos estudos de mídia, religião, política e cultura, após encontro ocorrido no II Seminário Internacional de Pesquisa em Midiatização e Processos Sociais, realizado na Unisinos, no Rio Grande do Sul. 
Fonte: As autoras (2018).

Na Figura 3, MCM são os meios de comunicação de massa; LO é o líder de opinião da atualidade, presente nas mídias digitais, meios de comunicação de massa e fora da mídia, como, por exemplo, Malafaia no púlpito. MD são mídias digitais, em que estão também os influenciadores digitais. Os liderados não têm a limitação de acesso aos meios, como no contexto estudado por Lazarsfeld ${ }^{3}$; apesar disso, seguem a representação do líder de opinião. Líderes e liderados estão ambientados no fenômeno da midiatização, portanto atravessados pela mídia em todos os aspectos e esferas da vida. O líder de opinião funciona como referencial para a sociedade.

A internet contribuiu para a modificação da comunicação e do relacionamento interpessoal, dando ao usuário maior liberdade de escolha do conteúdo a ser consumido e compartilhado. Com esse modelo, o líder de opinião torna-se mais acessível, acompanhado por muitos de maneira não programática, em especial, a partir das redes sociais, ultrapassando distâncias em um tempo encurtado, e reunindo seguidores com interesse prévio na persona ou conteúdo e ideias por ele compartilhados, creditando confiança no mesmo em um cenário no qual interação e influência se afetam. A relação pode se estreitar concebendo a manutenção de vínculo com a comunidade, a exemplo da atuação dos líderes religiosos, como é o caso do pastor evangélico Silas Malafaia.

\section{Silas Malafaia e a 'ideologia de gênero' nas mídias digitais}

Malafaia é pastor neopentecostaliii da igreja evangélica Assembleia de Deus Vitória em Cristo, graduado em psicologia, fundador da Associação Vitória em Cristo e empresário, dono das empresas: editora Central Gospel, serviço de streaming ${ }^{\text {iv }}$ Gospel Play, portal de notícias Verdade Gospel e gravadora Central Gospel Music. Ficou conhecido pelo programa de televisão Vitória em Cristo no ar há mais de 35 anos, fundado e apresentado por ele. Exibido semanalmente na RedeTV!, o programa também é transmitido em outros países. Cabe salientar que a atuação multifuncional não é exclusiva de Malafaia. Outras lideranças religiosas evangélicas também possuem empreendimentos comerciais e, em especial, no ramo das comunicações, a exemplo do Edir Macedo, dono da Record e fundador da Igreja Universal do Reino de Deus.

Silas Malafaia é muito conhecido no meio evangélico e fora dele por conta de manifestar opinião sobre assuntos polêmicos e de interesse público. Sua projeção e relevância também se mostram nas redes sociais, onde somados todos os seus seguidores, é acompanhado por mais de cinco milhões de pessoas que seguem o conteúdo compartilhado por ele diariamente. Somente no Twitter, o pastor já realizou quase quarenta mil postagens e possui um milhão e trezentos e oitenta mil seguidores.

Retomando o objetivo deste estudo, buscaremos compreender como os líderes de opinião, a exemplo de Malafaia, atuam na sociedade midiatizada, corroborando sua influência sobre a opinião pública de nichos específicos a respeito de assuntos de interesse social, como os que tangem à área da saúde tal qual a identidade de gênero. A escolha pelo termo 'ideologia de gênero' atrelada ao pastor Malafaia se deu a partir de sua adesão ao termo e ao próprio Google Trends que apontou ser um dos vocábulos mais buscados junto ao nome do líder no recorte de tempo estudado. Além disso, apesar de tratar de outras temáticas no período, conforme veremos posteriormente, essa foi a que predominou em seus tweets.

A adoção da expressão ‘ideologia de gênero’ no mundo evangélico vem principalmente da bancada evangélica em contraposição à discussão de gênero nas escolas, estabelecida como uma das diretrizes do Plano Nacional de Educação proposto em 2014. Apesar de objetivar uma educação inclusiva, o

\footnotetext{
iii Terceira vertente neopentecostal, que se caracteriza por priorizar manifestações dos dons do Espírito Santo, como o falar em línguas espirituais, bem como pelo amplo uso da mídia.

iv Transmissão instantânea de dados por meio da internet.
} 
respeito à diversidade e o combate ao preconceito, o plano foi mal visto pela bancada evangélica, que pressionou a retirada dos termos relacionados a gênero e sexualidade para que o Plano fosse aprovado. A forte oposição conservadora aos estudos de gênero parte do pressuposto que tais estudos contrariam a natureza divina da criação de homem e mulher, além de aniquilar o projeto divino de família entendido na formação homem, mulher e filhos.

Diante disso, como dito na Introdução deste artigo, o recorte de tempo escolhido tratado período que se estende de 9 de setembro de 2017 a 9 de dezembro de 2017. Trata-se do ápice da busca do assunto 'ideologia de gênero' no ano de 2017, de acordo com apontamento da ferramenta Google Trends ${ }^{\mathrm{v}}$. O termo esteve em intensa ascensão no período em questão, tendo ápice entre os dias 15 de outubro de 2017 e 4 de novembro de 2017, conforme demonstra a Figura 4.

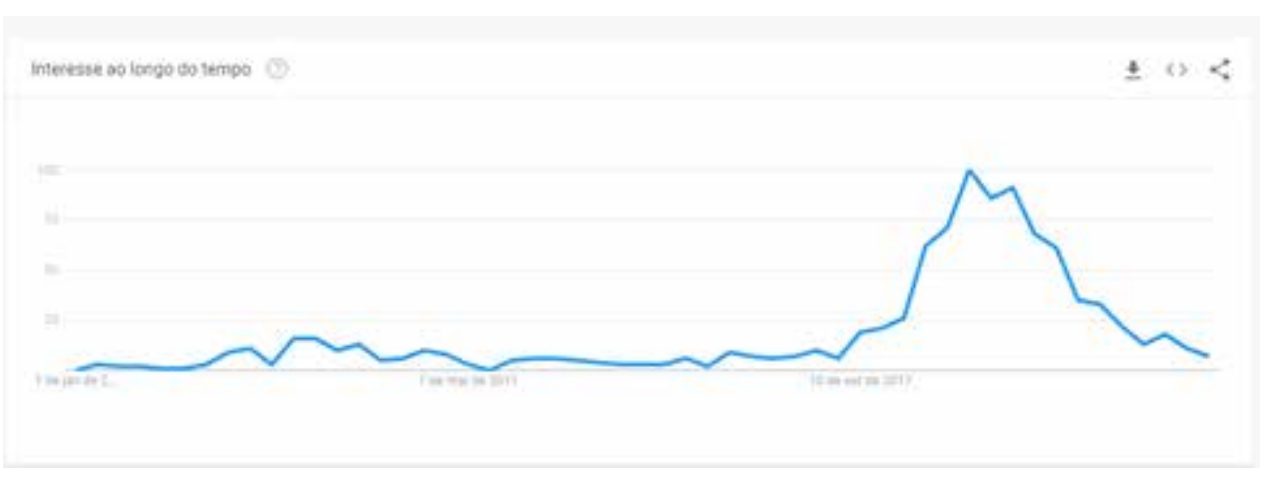

Figura 4 - Busca da expressão 'ideologia de gênero' no ano de 2017 Fonte: Google Trends (2018).

Nota-se, no entanto, que outra expressão designada para abordar o assunto ('identidade de gênero') não sofreu intensa ascensão somente no período estudado. Antes, teve uma procura mais frequente no decorrer do ano. Apesar disso, o ápice de buscas também se deu no período em questão, durante os meses de outubro e novembro, conforme mostra a Figura 5.

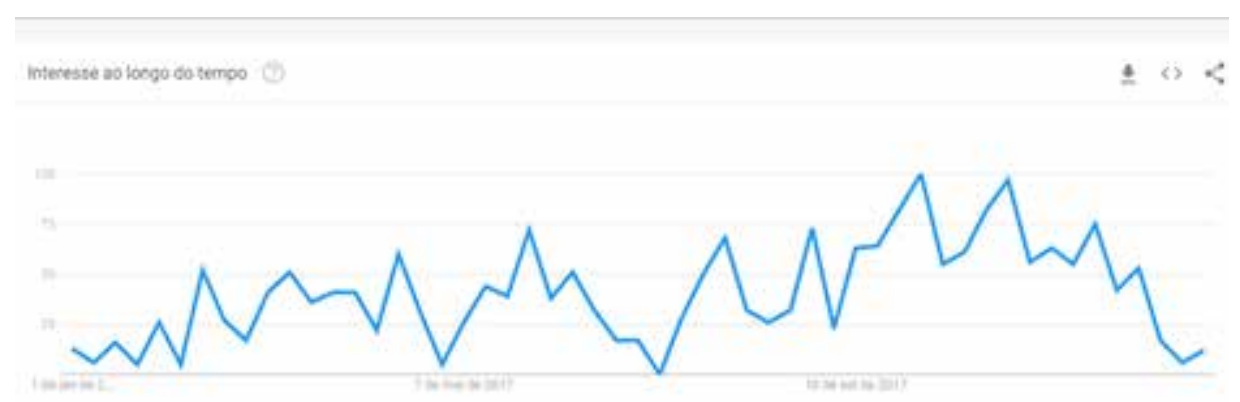

Figura 5 - Busca da expressão 'identidade de gênero' no ano de 2017

Fonte: Google Trends (2018).

Os assuntos relacionados às buscas também se diferenciam nos termos. 'Ideologia de gênero' aparece relacionada aos assuntos dispostos em ordem decrescente: ciência; religião; conceito; Judith Butler; redação (cargo); estudos de gênero; sexualidade humana e argumento. Já a busca de 'identidade de gênero' relaciona-se aos assuntos também dispostos em ordem decrescente: redação (cargo); discriminação; intersexualidade; política; direito (campo de estudo); violência; direitos humanos; binário de gênero; transexualidade; conceito; orientação sexual; transgênero e transtorno de identidade de gênero. As distinções nos assuntos relacionados demarcam a diferença dos indivíduos que buscam os termos e suas respectivas visões a respeito do tema. O primeiro, 'ideologia de gênero' é associado enquanto interesse da religião, o que não ocorre com o segundo, 'identidade de gênero'.

v Ferramenta gratuita do Google que permite apontar o desenvolvimento de buscas de termos, expressões ou palavras-chave ao longo do tempo, mostrando as principais tendências de busca. Disponível em: https://trends.google.com.br Acesso em 19 jul. 2018. 
Uns enxergam enquanto 'ideologia' e outros como campo científico concernente à biologia e cultura. Neste estudo, optamos por trabalhar com o termo 'ideologia de gênero', entendendo que alguns religiosos, como parte dos evangélicos, adotam este vocábulo, além do líder Silas Malafaia fazer amplo uso do termo a partir do seu ponto de vista, conforme vimos antes. Isso se dá por conta do entendimento das questões de gênero justificadas somente pelo sexo biológico, rejeitando que existem afetos sociais e culturais. É o que pastor quer dizer ao falar durante o período de análise que "Homem nasce homem, mulher nasce mulher. E nenhuma ideologia social mudará isso"²3. Falaremos da colocação a seguir. Por isso, a palavra 'ideologia' é utilizada para deslegitimar os estudos sobre gênero, conferindo características de ideais e paixões movidas por uma ideologia acusada de ter como propósito corromper as instituições sociais, como a 'família tradicional'. Geralmente, tais inculpações são atreladas às correntes de esquerda.

É necessário entender o contexto que envolve a exponencial ascensão da busca dos termos no recorte de tempo estudado, considerando o processo de midiatização, em que grande mídia e mídias digitais coexistem e líderes de opinião alimentam tanto o ambiente midiático, como o externo. Para isso, traçamos uma linha do tempo, por meio de pesquisa documental em sites de notícias com os acontecimentos em questão, abrangendo desde o dia 9 de setembro de 2017, quando a busca do vocábulo 'ideologia de gênero' começou a crescer, até 9 de dezembro de 2017, quando diminui e se estabiliza.

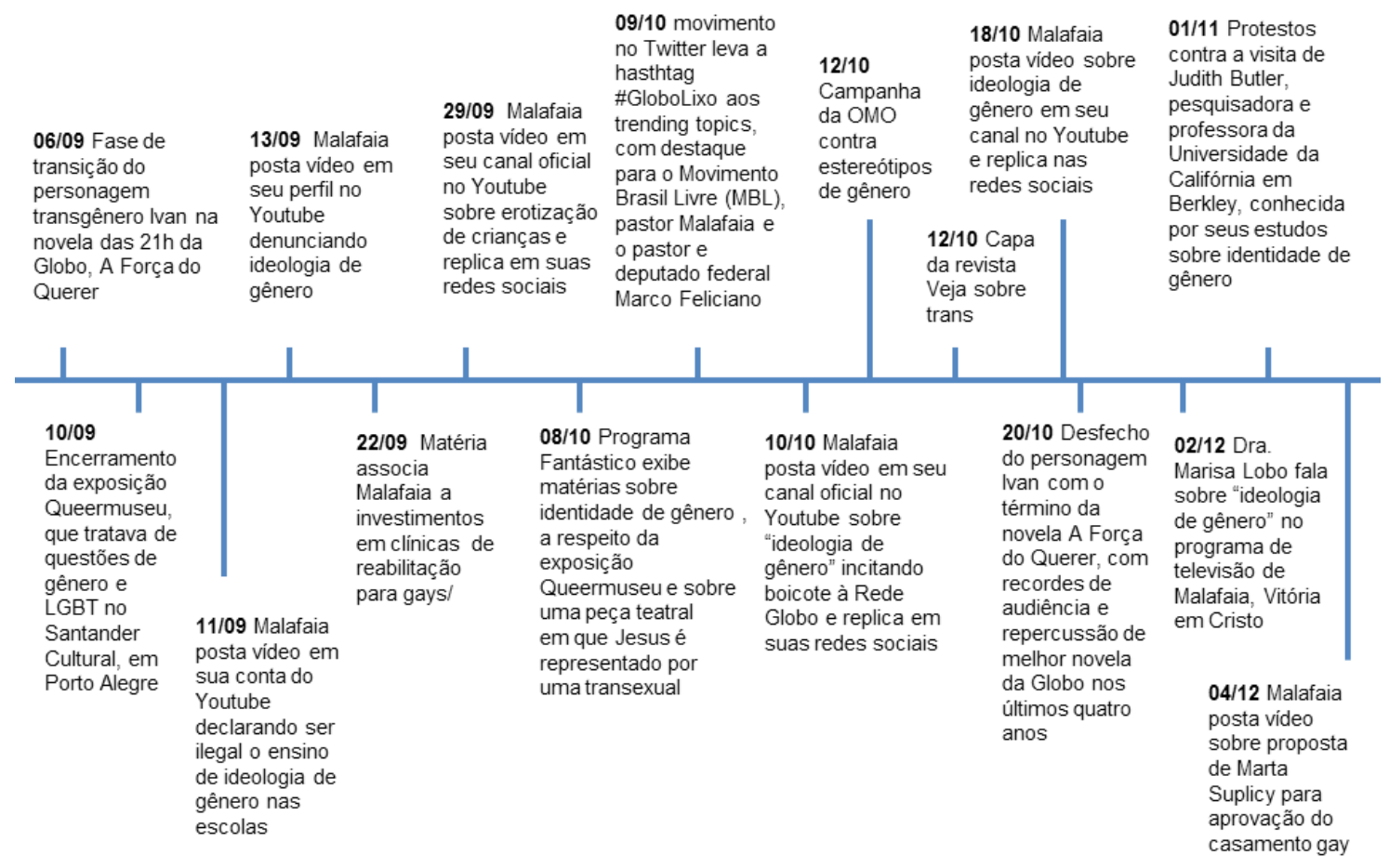

Figura 6 - Linha do tempo com acontecimentos de 09/09/17 a 09/12/17

Fonte: As autoras (2018).

Na cronologia, é possível perceber como acontecimentos que envolvem questões de gênero marcaram o período de ascensão da busca dos termos. O contexto envolve a abordagem da transição de gênero de um personagem em uma novela no horário nobre da televisão brasileira (A Força do Querer), a exposição Queermuseu no Santander Cultural, em Porto Alegre, e seu posterior encerramento pela forte repercussão, exibição de matéria no Fantástico sobre identidade de gênero e defesa da exposição como forma de arte, campanha da OMO (empresa de sabão em pó) em comemoração ao dia das crianças contra o estereótipo de gênero e capa da revista Veja sobre transgêneros. Em todas as fases, Malafaia demonstra sua característica de líder de opinião evangélico, recontando os fatos, adaptando- 
os ao nicho evangélico e atuando fortemente nos meios de comunicação de massa, mídias digitais e fora da mídia, como quando leva a temática para o púlpito da igreja.

A pesquisa do nome 'Silas Malafaia' no Google Trends com base nos últimos doze meses revela que entre os assuntos relacionados a ele em ascensão, na ferramenta de busca, estão: gênero (ciências sociais); homossexualidade (assunto) e estudos de gênero (campo de estudo). Além disso, a terceira principal frase relacionada ao pastor é 'Silas Malafaia fala sobre novela da Globo', em ascensão no desfecho da história que retrata a transição de gênero do personagem Ivan, de 29 de outubro de 2017 a 4 de novembro de 2017, período de ápice da busca de 'ideologia de gênero'. Isso demonstra como a manifestação da sua opinião sobre o tema é procurada como referência para um nicho específico que deposita confiança nele baseada na fé em sua autoridade como líder religioso.

$\mathrm{Na}$ ocasião, houve forte exploração do conteúdo audiovisual, como de costume para o pastor que se consagrou na televisão. Ao todo, foram publicados no canal oficial de Malafaia no Youtube ${ }^{\text {vi }}$ dez vídeos sobre a temática 'ideologia de gênero', envolvendo denúncia de erotização de crianças no episódio do Queermuseu, boicote à Rede Globo, ensino de 'ideologia de gênero' nas escolas, 'cura gay' e casamento gay. As publicações somam mais de 520 mil visualizações. Com destaque para o vídeo em que o pastor denuncia "o jornalismo bandido do Fantástico da Rede Globo" 24 com mais de 160 mil visualizações, publicado em 9 de outubro de 2017; e para a publicação feita em 29 de setembro de 2017, que se chama "bandidos! Erotizando crianças em nome da arte" ${ }^{25}$, com quase 100 mil visualizações.

Vale ressaltar como Malafaia utiliza as diferentes redes sociais com produção de conteúdo específica para cada uma delas. O líder está presente no Twitter, Youtube, Facebook ${ }^{\text {vii }}$ e Instagram $^{\text {viii }}$. No Twitterix, as postagens foram intensas no período. De acordo com pesquisa realizada anteriormente ${ }^{26}$, trata-se da rede social a que o pastor recorre mais vezes, especialmente para discutir temas políticos, por conta do imediatismo característico devido ao número de caracteres reduzidos. Considerado um dos maiores influenciadores políticos do Twitter ${ }^{x}$, Malafaia é conhecido por tratar de assuntos polêmicos de modo incisivo em defesa da moral cristã e dos valores da família, o que rende opiniões controversas referentes às questões políticas, homoafetivas, legalização do aborto e, também, identidade de gênero. O pastor foi muito ativo no período, ao tratar das questões de gênero como ideologia associada aos 'esquerdopatas' e gays, responsáveis - na sua opinião - por toda espécie de 'lixo moral' e destruição dos valores da família. É recorrente a associação da esquerda ao papel de vilã das histórias proferidas por Malafaia. Por exemplo, em estudo recente que averiguou como ele utilizou a retórica da intransigência para se opor a Marcelo Freixo - até então, deputado federal, candidato a prefeito na cidade do Rio de Janeiro e principal opositor de Marcelo Crivella nas eleições municipais cariocas de $2016^{27}$, assim sendo, a personificação da esquerda.

Para compreender como as questões de gênero foram transmitidas pelo líder de opinião evangélico aos seus seguidores, foi realizada uma análise de abordagem qualitativa em seu perfil no período que compreende a ascensão do termo 'ideologia de gênero' no Google Trends. A análise foi feita com o auxílio da ferramenta de busca avançada do Twitter que possibilita encontrar os tweets ${ }^{\mathrm{xi}}$ do recorte em questão. A partir do texto colhido, foi feita uma nuvem de palavras, com o auxílio da ferramenta online WordArt, em que as palavras se organizam em níveis de hierarquia. As de maior destaque são as que têm mais recorrência no texto.

\footnotetext{
vi Site em que são compartilhados vídeos pelos usuários por meio da internet.

vii Rede social que permite a conexão com amigos e familiares com o envio de fotos, vídeos e mensagens.

viii Rede social em que o foco é o compartilhamento de imagens e vídeos com edição de fotos por meio de filtros digitais.

ix Microblog em que são enviadas e recebidas mensagens de caracteres reduzidos pelos usuários.

x Disponível em: https://veja.abril.com.br/blog/a-origem-dos-bytes/twitter-os-maiores-influenciadores-politicos-da-rede/ Acesso em 25 jul. 2018.

xi Postagens no Twitter.
} 


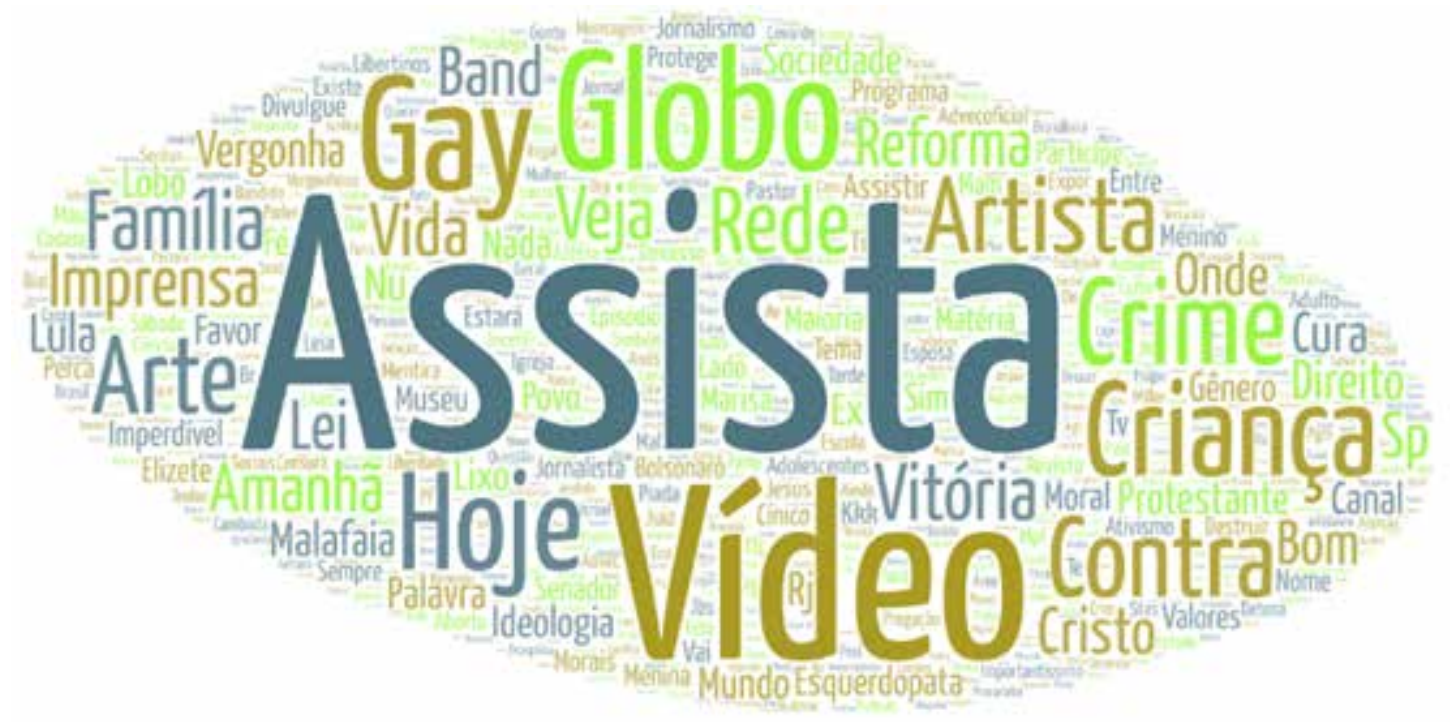

Figura 7 - Mapa conceitual das expressões utilizadas por Malafaia Fonte: As autoras (2018)

Por explorar o conteúdo audiovisual em seu posicionamento contra a ideologia de gênero, a palavra 'Assista' e 'Vídeo' são as de maior relevância, pois direcionam os seguidores a assistirem os vídeos, por meio dos quais ele também se manifesta. A palavra 'Gay' apresenta grande destaque, já que muitas vezes Malafaia as utiliza indistintamente, referindo-se ao 'ativismo gay' junto aos 'esquerdopatas' (outra palavra recorrente) como culpados pela erotização de crianças e naturalização da pedofilia, por conta da permissão de crianças em exposições com conteúdo de nudismo. Para o líder, os gays são uma minoria que desejam implantar uma "ditadura gay" ${ }^{28}$ para implementar seus valores. O vocábulo também é frequente para referirse à 'cura gay'. Vale destacar que o pastor é réu em ação que o acusa de homofobia ${ }^{\text {xii }}$

As palavras 'Rede', 'Globo', 'Imprensa' e 'Veja' demonstram o posicionamento de descontentamento do pastor com a mídia, declarando que a Rede Globo só tem um lado: a defesa dos esquerdopatas e do ativismo gay. Malafaia incita o boicote à Rede Globo, por conta das matérias veiculadas no programa dominical Fantástico e comemora o trending topics ${ }^{\text {xiii }}$ da campanha '\#Globolixo'. A palavra 'Veja' refere-se à revista, indicada por Malafaia como "nova trincheira do ativismo gay"29 por conta de matéria de capa que aborda questão trans.

Silas Malafaia 0 @astorMalafaia - 9 de out de 2017

\#Globolixo no primeiro lugar do Trending Topics do twitter. A revolta da sociedade contra esse sistema devasso.
213
[] 1,0 mil
3,1 mil

Figura 8 - Tweet de Silas Malafaia comemorando \#GloboLixo no trending topics Fonte: Twitter (2017).

'Arte', 'Artista', 'Crime' e 'Criança' se destacam, pois Malafaia argumenta ser crime expor crianças ao nudismo, com base no artigo 79 do Estatuto da Criança e do Adolescente (ECA) ${ }^{30}$. O líder de opinião costuma basear suas afirmações, conferindo status de legitimidade e transmitindo confiança no que diz. Assim, o pastor justifica o uso da palavra 'ideologia' para tratar de gênero ao se alicerçar em sua formação como psicólogo. Ele fundamenta que as características comportamentais de homens e mulheres estão na genética e não têm a ver

xii Malafaia criticou a Parada do Orgulho LGBT em 2016 durante seu programa na televisão, dizendo que "Os caras na parada gay ridicularizaram símbolos da Igreja Católica e ninguém fala nada. É pra Igreja Católica entrar de pau em cima desses caras, sabe? Baixar o porrete em cima pra esses caras aprender (sic). É uma vergonha". Disponível em: https://politica.estadao.com.br/blogs/fausto-macedo/tribunalmanda-retomar-acao-contra-malafaia-por-homofobia/ Acesso em 25 jul. 2018.

xiii Assuntos mais falados do momento no Twitter. 
com convívio social ou cultural ${ }^{31}$. Malafaia diz que os cristãos são maioria e precisam se posicionar contra a minoria que deseja minar os valores da família ${ }^{32}$. Aos que defendem o 'lixo moral' a que denomina a 'ideologia de gênero', 'erotização de crianças' e naturalização da pedofilia, Malafaia se refere ainda como: "covardes”33, "cínicos"33, "devassos" ${ }^{2}$, "libertinos"32, "cambada" ${ }^{2}$ e "inescrupulosos"32, fazendo constante relação ao sentimento de "vergonha" (ou vergonhoso) ${ }^{34}$, outra palavra recorrente. 'Família' se destaca, pois a todo momento é colocada como uma instituição sob ataque; por isso, o pastor alerta a respeito de sua proteção.

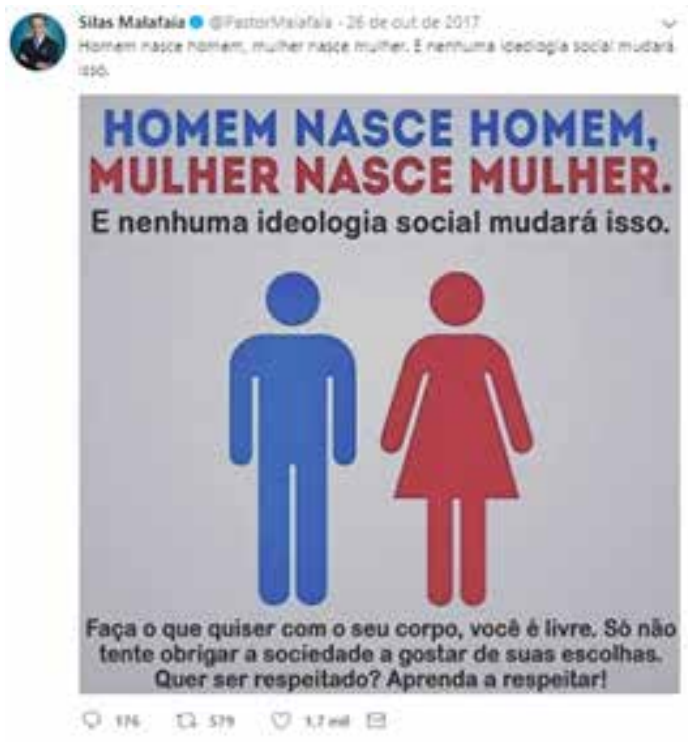

Figura 9 - Tweet de Silas Malafaia sobre 'ideologia de gênero' Fonte: Twitter (2017).

Logo, o que se vê é um tratamento equiparado das questões de gênero ao sexo biológico. Além disso, não há reconhecimento do contexto cultural e social atrelado ao desenvolvimento do sujeito. Os episódios envolvidos no contexto são dissolvidos como frutos do 'ativismo gay' e da 'cambada de esquerdopatas', lançando todas as possíveis reflexões ao mesmo patamar da erotização infantil, pedofilia e imoralidade. Ao ignorar os estudos de gênero como campo científico e atrelá-los a uma ideologia social, Malafaia utiliza dados que alicerçam suas falas, a fim de travestir a opinião de discurso legítimo.

\section{Considerações finais}

Portanto, a formulação do líder de opinião concebida por Lazarsfeld ${ }^{3}$ se deu em um cenário que se difere muito do atual. A década de 1940 é caracterizada pela massa, tanto na cultura, quanto na sociedade e comunicação. Nem todos tinham meios de comunicação, o que tornava a atribuição do líder um importante filtro para a difusão de informação no âmbito interpessoal. O uso da televisão era incipiente e prevaleciam o rádio e jornal. Com a crescente popularização dos MCM e o fortalecimento da indústria da mídia nos anos seguintes, gradativamente, as relações sociais e o cotidiano foram atravessados por esses meios, sendo afetados e modulados por valores, pensamento e comportamentos inseridos em uma relação de poder da mídia como instituição que atua sobre as demais.

O líder de opinião contemporâneo não é mais o filtro de informação entre os meios e as outras pessoas na comunicação interpessoal. Sua posição é de referência de comportamento e valores para os outros de seu nicho, conforme vemos quando Silas Malafaia é associado aos estudos de gênero nos mecanismos de busca, visto que ambos se encontram no interior da ambiência midiática. A apreensão da opinião emitida varia conforme os interesses comuns que unem influenciador e influenciado. O líder não atua somente na esfera interpessoal, mas enquanto ambiência, age na grande mídia, nas novas mídias e fora delas. As mídias digitais e a internet permitiram certa horizontalização na emissão e difusão de conteúdo entre as 
pessoas, o que deu espaço para a emergência do influenciador digital cuja prática chega a ser até mesmo prática profissional, ocupando papel que se difere do líder nos níveis operantes da comunicação. Por isso, alguns indivíduos continuam exercendo maior influência em detrimento de outros, já que podem se basear na superação da interação e na fortificação de um nexo, baseado seja na opinião política, seja na fé, seja na união estratégica entre um e outro.

\section{Referências}

1. Sodré M. Antropológica do espelho. Petrópolis: Vozes; 2002.

2. Heller A. O cotidiano e a história. Rio de Janeiro: Paz e Terra; 2000.

3. Lazarsfeld P, Berelson B, Gaudet H. The People's Choice. Nova York: Columbia Univ. Press; 1948.

4. Martino LMS. Teoria das mídias digitais. Petrópolis: Vozes; 2014.

5. Recuero R. A Conversação em rede: comunicação mediada pelo computador e redes sociais na internet. Porto Alegre: Sulina; 2012.

6. Internet é a primeira fonte de informações para $47 \%$ dos brasileiros, aponta estudo. Ibope [Internet]; 2014 [citado 2018 jul. 23]. Disponível em: https://goo.gl/8hup7Y

7. Villas Bôas, B. Acesso à internet pela TV dispara em 2017, revela IBGE. Valor [Internet]; 2018 [citado 2018 mar. 3]. Disponível em: https://goo.gl/GuXoDQ

8. Dino. Pesquisa coloca Brasil no topo de ranking de acessos online, mostra José Borghi. Exame [Internet]; 2016 [citado 2018 mar. 12]. Disponível em: https://goo.gl/tq4zTY

9. Agência Brasil. Brasil é o $4^{\circ}$ país em número de usuários de internet: com 120 milhões de pessoas conectadas, o Brasil fica atrás apenas dos Estados Unidos (242 milhões), Índia (333 milhões) e China (705 milhões). Exame [Internet]; 2017 [citado 2018 jan. 28]. Disponível em: https://goo.gl/MduJ3T

10. Wolf M. Teorias das comunicações de massa. São Paulo: Martins Fontes; 2008.

11. Cervi EU. Opinião pública em sociedades complexas e processos horizontais de comunicação: A contribuição de Luiz Beltrão para o processo de formação de Opinião. Pública em sociedades complexas [Internet]; 2011 [citado 2018 mar. 4]. Disponível em: http://www.compolitica.org/home/wp-content/ uploads/2011/01/gt csc-emerson.pdf

12. Zaller JR. The Nature and Origins of Mass Opinion. New York: Cambridge University Press; 1992.

13. Merton R. Social Theory and Social Structure. New York: FreePress; 1949.

14. Morgado, Isabel. A pressão política sobre os líderes de opinião: a luta pela soberania do tempo. In: Correia, JC, organizador. Comunicação e política. Covilhã: UBI; 2005. p.115-45. (Coleção Estudos em Comunicação).

15. Barbero JM. Dos meios às mediações. Rio de Janeiro: UFRJ, 1997.

16. Franco SM, Leão ALMS. Midiatização: da disciplina ao controle, um horizonte de reflexão. Rev Front Estud Midia. 2016 set;18(3):289-304. doi: http://dx.doi.org/10.4013/fem.2016.183.06

17. Sodré M. A ciência do comum: notas para o método educacional. Petrópolis: Vozes; 2015.

18. Saldanha PG. A ciência do comum: a transcendência do bios midiático que reordena as vinculações cotidianas. Rev Latinoam Cienc Comun [Internet]; 2017 jun [citado em 2018 mar. 4];13(25):191-5. Disponível em: https://www.alaic.org/revista/index.php/alaic/article/view/855

19. Uslaner. EM. Social capital and the net. Commun ACM. 2000;43(12):60-4.

20. Marques FPJ. Ciberpolítica: conceitos e experiências. Salvador: EDUFBA; 2016.

21. Karhawi, I. Influenciadores digitais: o Eu como mercadoria. In: Saad E, Silveira SC, organizadoras. Tendências em Comunicação Digital. [Internet] São Paulo: ECA/USP; 2016 [citado em 2018 mar. 4]. p. 38-58. Disponível em: https://goo.gl/27Rt3D

22. Karhawi I. Influenciadores digitais: conceitos e práticas em discussões. Rev Commun [ Internet]. 2017 [citado em 2018 mar. 4];17(Edição Especial de 70 anos da Faculdade Cásper Líbero):46-61. Disponível em: https://goo.gl/pBEop8 
23. Malafaia S. Postagem do Twitter: Homem nasce homem, mulher nasce mulher. E nenhuma ideologia social mudará isso [Internet]. 26 de outubro de 2017, 07:12 [citado em 2018 jul. 20]. Disponível em: https://twitter.com/PastorMalafaia/status/923552955890053120

24. Malafaia S. O jornalismo bandido do Fantástico da Rede Globo [Internet]. 09 de outubro de 2017 [citado em 2018 jul. 20]. Disponível em: https://www.youtube.com/watch?v=6iEFfwISdJQ

25. Malafaia S. Pr. Silas Malafaia comenta: BANDIDOS! Erotizando crianças em nome da arte [Internet] 29 de setembro de 2017 [citado em 2018 jul. 20] Disponível em: https://www.youtube.com/watch?v=LhwWEzjHxzk

26. Cesar LO, Saldanha PG. Comunicação social e formação de opinião política no Twitter: o líder evangélico Silas Malafaia. In: $40^{\circ}$ Congresso Brasileiro de Ciências da Comunicação [Internet]; 2017 set 04-09; Curitiba, PR. São Paulo: Intercom; 2018 [citado em 2018 jul. 23].Disponível em: https://goo.gl/ghbXCv

27. Cesar LO, Cunha VCC. \#ChoremEsquerdopatas: a retórica da intransigência de Malafaia como estratégia de apoio político a Crivella na eleição municipal carioca de 2016. Entremeios [Internet]. 2018 [citado em 2019 fev. 04];14(1):1-14. Disponível em: http://entremeios.com.puc-rio.br/media/Cesar e Cardoso Esquerdopatas.pdf

28. Malafaia S. A ditadura gay não suporta a liberdade de expressão dos outros,só a deles [Internet]. 24 de abril de 2015, 06:18 [citado em 2018 jul. 20]. Disponível em: https://twitter.com/pastormalafaia/ status/591593467102498816

29. Malafaia S. Se não bastasse o jornal o globo, agora, a revista veja é a nova trincheira do ativismo gay [Internet]. 13 de outubro de 2017, 16:11 [citado em 2018 jul. 21]. Disponível em: https://twitter.com/ PastorMalafaia/status/918977635346239488

30. Malafaia S. Postagem no Twitter: É crime! Artigo 79 do ECA impede expor crianças a esse tipo de situação que o MAM de SP está fazendo. Onde está o MPF? Onde está a OAB? [Internet]. 29 de setembro de 2017, 14:20 [citado em 2018 jul. 21]. Disponível em: https://twitter.com/PastorMalafaia/status/913876236681842692

31. Malafaia S. Postagem no Twitter: A própria natureza mostra a diferença entre masculino e feminino, a genética também, as olimpíadas idem. Esses esquerdopatas são uma piada [Internet]. 05 de agosto de 2016 [citado em 2018 jul. 21] Disponível em: https://twitter.com/PastorMalafaia/status/761691079083261952

32. Malafaia S. Para os devassos e libertinos, onda conservadora é proteger as crianças e a família. CAMBADA DE INESCRUPULOSOS! Ñ vão intimidar a maioria [Internet]. 04 de novembro de 2017 [citado em 2018 jul. 21] Disponível em: https://twitter.com/PastorMalafaia/status/926928618701418498

33. Malafaia, S. O CINISMO DO JORNAL O GLOBO.Tenta induzir o leitor a acreditar q museu em Paris permite exibir nu para crianças.MENTIRA! COVARDES! CÍNICOS! [Internet]. 04 de outubro de 2017, 12:29 [citado em 2018 jul. 22]. Disponível em: https://twitter.com/PastorMalafaia/status/915660274941796353

34. Malafaia S. É INCRÍVEL! O cinismo da imprensa em querer proteger esses criminosos em nome da arte. Omissos! Covardes! Vergonhoso! [Internet]. 02 de outubro de 2017 [citado em 2018 jul. 22]. Disponível em: https://twitter.com/PastorMalafaia/status/915047957766000640 